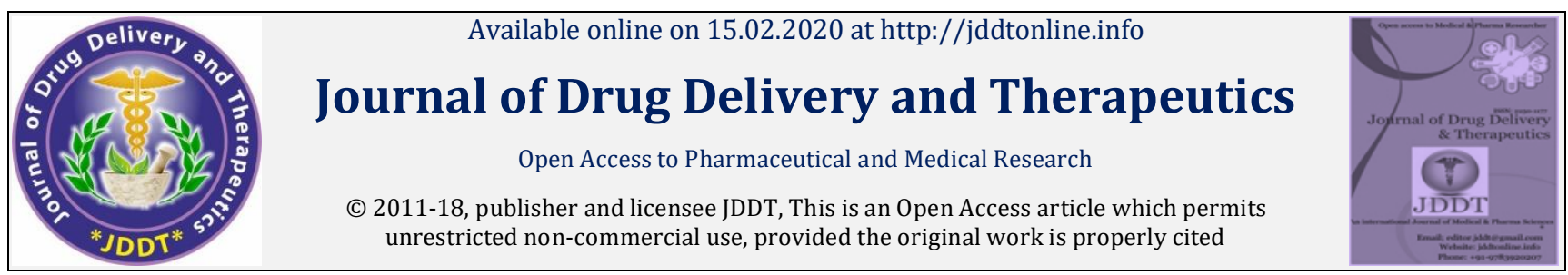

Open $\odot$ Access

Research Article

\title{
Antioxidant, antimicrobial and anti-inflammatory activities development of methanol extract of Cyclamen africanum B. et R., growth in Jijel - Algeria
}

\author{
Gaamoune Sofiane a and Nouioua Wafa ${ }^{b *}$ \\ a National Institute of Agricultural Research - Setif - Algeria \\ b Faculty of Natural Life and Sciences, University Ferhat Abbas Setif, Algeria
}

\begin{abstract}
The genus Cyclamen L. (Primulaceae) is represented by 20 species, where inter alia Cyclamen africanum B. et R, is the only endemic species presented in Algeria. The study of their biological potentialities was evaluated through antioxidant, antimicrobial and anti-inflammatory activities. The antioxidant activity was evaluated by DPPH and the reducing power essay, the antimicrobial activity was tested with three bacterial strains and one yeast (Staphylococcus aureus ATCC25923, Klebsiella pneumonia ATCC700603, Bacillus subtilis ATCC6633 and Candida albicans ATCC1024) and anti-inflammatory activity with the Human Red Blood Cell (HRBC) membrane stabilization method. The results demonstrate a perfect antioxidant activity and an excellent anti- inflammatory power at very small concentrations.
\end{abstract}

Keywords: Cyclamen; crude extract; reducing power; antimicrobial; HRBC.

Article Info: Received 24 Nov 2019; Review Completed 18 Jan 2020; Accepted 27 Jan 2020; Available online 15 Feb 2020

Cite this article as:

Sofiane G, Wafa N, Antioxidant, antimicrobial and anti-inflammatory activities development of methanol extract of Cyclamen africanum B. et R., growth in Jijel - Algeria, Journal of Drug Delivery and Therapeutics. 2020; 10(1-s):130-134 http://dx.doi.org/10.22270/jddt.v10i1-s.3883

口. *Address for Correspondence:

Nouioua Wafa, Faculty of Natural Life and Sciences, University Ferhat Abbas Setif, Algeria

\section{INTRODUCTION}

Cyclamen L. is a small genus of the Primulaceae [1]. Consists of more than 20 species with highest diversity [2] distributed the Mediterranean region, Central Europe, the Caucasus and northern Somalia [1]. Some species have been cultivated in Western European countries since the $18^{\text {th }}$ century [3]. Although, Cyclamen species are in the list of CITES (Convention on International Trade in Endangered Species of wild fauna and flora) [4], several species are widely used in traditional folk medicine for their laxative and abortive [5], sedative, purgative, emmenagogue and anti-helmintic properties [6].

Botanically, Cyclamen africanum B. et R., is a perennial plant with tuberculous strain. Their leaves are cordifoitlles petiolate and their flowers are scapiform with petals reflected above the tube, nutantes at anthesis. It flowering in autumn, with flower preceding the leaves $(6-15 \mathrm{~cm})$, spotted with red more or less dented, crenelated on the margins. Tubers are very bulky. Large flowers $(2-3,5 \mathrm{~cm})$, with toothed groove. Peduncle retracting into a cork after flowering. This species is a North African endemic prefer the forests and the scrub, can be found in the Tell, Algerian littoral and Constantine [7].

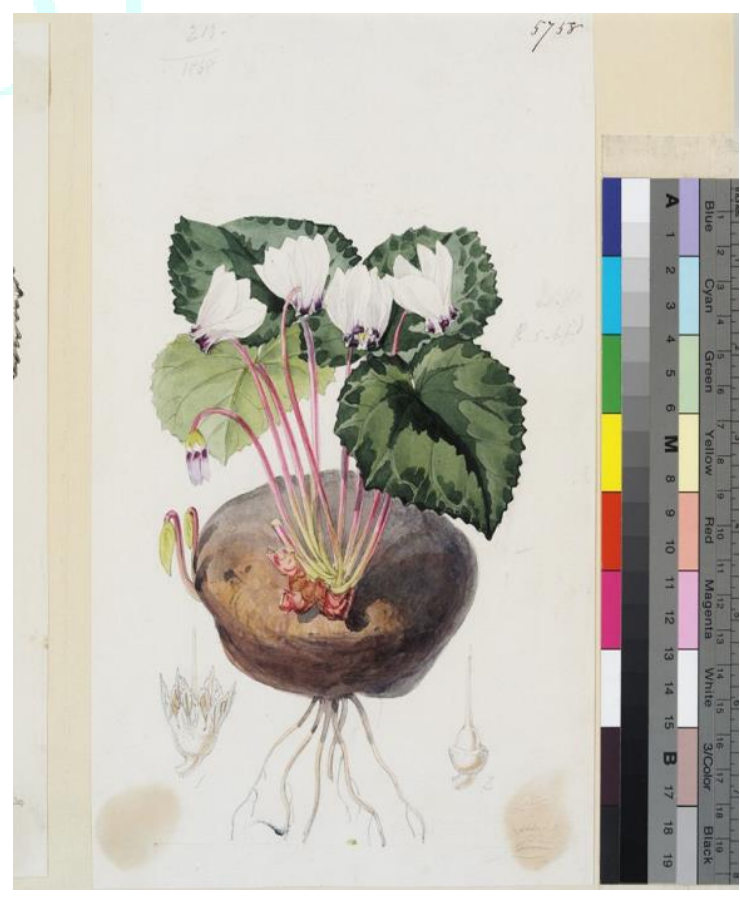

Figure 1: Cyclamen africanum Boiss. \& Reuter original illustration from Curtis's Botanical Magazine (1869) 
In this study, we adapted these protocols for $C$. africanum. In detail, the aim was to valorise their biological activities to enrich the Algerian pharmacopeia and to preserve this endemic species from extinction.

\section{MATERIALS AND METHODS}

\section{Plant material}

The random sampling were used during the harvesting, the areal parts of Cyclamen africanum $B$. et $R$., were harvested from Taza National Park Jijel - Algeria $\left(36^{\circ} 35^{\prime} 16^{\prime \prime}-36^{\circ} 48^{\prime}\right.$ $12^{\prime \prime}$ north Latitude and between $5^{\circ} 29^{\prime} 07^{\prime \prime}$ and $5^{\circ} 40^{\prime} 11^{\prime \prime}$ Longitude East); Determined by Dr. Nouioua Wafa.

\section{Preparation of methanol extract}

The areal parts were powdered and macerated in $80 \%$ methanol for 24, 48 and 72 hours, at the laboratory temperature $(1: 10 \mathrm{w} / \mathrm{v}, 10 \mathrm{~g}$ of dried herb). After maceration, the extracts were collected, filtered and evaporated to dryness under vacuum [8]. The dry extract was stored at a temperature of $-18^{\circ} \mathrm{C}$ for later use.

\section{Determination of Total Phenolic Content}

For total polyphenol determination, the Foline Ciocalteu method was used [9]. The samples $(0.2 \mathrm{~mL})$ were mixed with $1 \mathrm{~mL}$ of the Folin-Ciocalteu reagent previously diluted with $10 \mathrm{~mL}$ of deionized water. The solutions were allowed to stand for 4 minutes at $25{ }^{\circ} \mathrm{C}$ before $0.2 \mathrm{~mL}$ of a saturated sodium carbonate solution $(75 \mathrm{mg} / \mathrm{mL})$ was added. The mixed solutions were allowed to stand for another 120 minutes before the absorbance were measured at $765 \mathrm{~nm}$. Gallic acid was used as a standard for the calibration curve. The total phenolic compounds content was expressed as mg equivalent of Gallic acid per gram of extract (mg EAG/GE).

\section{Determination of total flavonoids content}

The flavonoids content in crude extract were estimated by the Aluminium chloride solution according to the method described by Bahorun et al., (1996) [10]. Briefly, $1 \mathrm{~mL}$ of the methanol solution of the extract was added to $1 \mathrm{~mL}$ of $2 \%$ $\mathrm{AlCl}_{3}$ in methanol. After 10 minutes, the absorbance was determined at $430 \mathrm{~nm}$. Quercetin was used as a standard. Results were expressed as mg equivalent Quercetin per gram of extract (mg EQ/GE).

\section{DPPH Assay}

The donation capacity of extract was measured by bleaching of the purple-coloured solution of 1, 1-diphenyl-2picrylhydrazyl radical (DPPH) according to the method of Hanato et al., (1998) [11]. One millilitre of the extract at different concentrations was added to $0.5 \mathrm{~mL}$ of a DPPHmethanol solution. The mixtures were shaken vigorously and left standing at the laboratory temperature for 30 minutes in the dark. The absorbance of the resulting solutions were measured at $517 \mathrm{~nm}$. The antiradical activity was expressed as $\mathrm{IC}_{50}$ (micrograms per millilitre). The ability to scavenge the DPPH radical was calculated using the following equation:

\section{DPPH scavenging effect $(\%)=\left[\left(A_{0}-A_{1}\right) / A_{0}\right] \times 100$}

Where: $A_{0}$ : the absorbance of the control at 30 minutes

$A_{1}$ : is the absorbance of the sample at 30 minutes. BHT was used as standard [12].

\section{Reducing power}

The reducing power was determined according to the method of Oyaizu (1986) [13]. The extract (2.5 mL) was mixed with $2.5 \mathrm{~mL}$ of $200 \mathrm{mmol} / \mathrm{L}$ sodium phosphate buffer
(pH 6.6) and $2.5 \mathrm{~mL}$ of $10 \mathrm{mg} / \mathrm{mL}$ potassium ferricyanide. The mixtures were incubated at $50{ }^{\circ} \mathrm{C}$ for 20 minutes; after cooling, $2.5 \mathrm{~mL}$ of $100 \mathrm{mg} / \mathrm{mL}$ trichloroacetic acid were added and the mixtures were centrifuged at $200 \mathrm{~g}$ for 10 minutes. The upper layer $(5 \mathrm{~mL})$ was mixed with $5 \mathrm{~mL}$ of deionized water and $1 \mathrm{~mL}$ of $1 \mathrm{mg} / \mathrm{mL}$ ferric chloride, and the absorbance was measured at $700 \mathrm{~nm}$ against a blank. A higher absorbance indicates a higher reducing power. $\mathrm{EC}_{50}$ value (mg extract/mL) is the effective concentration at which the absorbance was 0.5 for reducing power and was obtained by interpolation from linear regression analysis. BHA was used as standard [14].

\section{Antimicrobial activity}

Bacteria Strains were obtained from the American Type Culture Collection: Gram-positive bacteria (Staphylococcus aureus ATCC25923), Gram-negative bacteria (Klebsiella pneumoniae ATCC700603 and Bacillus subtilis ATCC6633) and yeast: Candida albicans ATCC1024. Muller Hinton agar was used for bacteria culture and Sabouraud for yeast.

\section{Anti-bacterial Activity}

Agar disc diffusion method was employed for the determination of antibacterial activities of C. africanum methanol extract [15] [16]. Briefly, a suspension of the tested microorganism $\left(10^{8} \mathrm{CFU} / \mathrm{mL}\right)$ was spread on the solid media plates. Filter paper discs $(6 \mathrm{~mm}$ in diameter $)$ were impregnated with $10 \mu \mathrm{L}(100 \mathrm{mg} / \mathrm{mL})$ of the extract and placed on the inoculated plates. These plates were incubated at $37{ }^{\circ} \mathrm{C}$ for 24 hours. Gentamicin $(10 \mu \mathrm{g} /$ disc $)$ was used as a standard and dimethylsulfoxide DMSO as a control.

The antibacterial activity was determined by measuring of inhibition zone diameters $(\mathrm{mm})$ and was evaluated according the parameters suggested by Alves et al. (2000) [17]:

- $\quad<9 \mathrm{~mm}$, inactive ;

- $\quad 9-12 \mathrm{~mm}$, less active ;

- $\quad 13-18 \mathrm{~mm}$, active;

- $\quad>18 \mathrm{~mm}$, very active.

\section{Antifungal activity}

The antifungal activity was tested by disc diffusion method with modifications [15]. Candida albicans ATCC1024 suspension was obtained in physiological saline $0.9 \%$ from a culture in Sabouraud (incubated before 24 hours at $37^{\circ} \mathrm{C}$ ), adjusted to $10^{5} \mathrm{CFU} / \mathrm{mL}$.

One hundred microliter of the suspension was placed over agar in Petri dishes and dispersed. Then, sterile paper discs (6 $\mathrm{mm}$ diameter) were placed on agar to load $10 \mu \mathrm{L}$ $(100 \mathrm{mg} / \mathrm{mL})$ of each sample. Amphotericin $100 \mu \mathrm{g}$ was used as standard and dimethylsulfoxide DMSO as control. Inhibition zones were determined after incubation at $27^{\circ} \mathrm{C}$ for 48 hours.

\section{The Human Red Blood Cell (HRBC) membrane stabilization method}

To prepare the HRBC suspension, fresh completely human blood $(10 \mathrm{~mL})$ was collected and transferred into the centrifuge tubes. These lasts were centrifuged at $3000 \mathrm{rpm}$ for 10 minutes thrice and washed with equal volume of normal saline each time. The volume of blood was measured and reconstituted as $10 \% \mathrm{v} / \mathrm{v}$ suspension with normal saline. 
The principle involved here was stabilization of human red blood cell membrane by hypo tonicity induced membrane

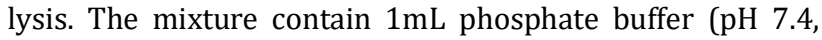
$0.15 \mathrm{M}), 2 \mathrm{~mL}$ hypo saline ( $0.36 \%), 0.5 \mathrm{~mL}$ HRBC suspension $(10 \% \mathrm{v} / \mathrm{v})$ and $0.5 \mathrm{~mL}$ of plant extract or standard drug (diclofenac sodium) at various concentrations $(10,50,100$, $250,500 \mu \mathrm{g} / \mathrm{mL}$ ). The control was distilled water instead of hypo saline to produce $100 \%$ haemolysis.

The mixtures were incubated at $37{ }^{\circ} \mathrm{C}$ for 30 minutes and centrifuged at $2500 \mathrm{rpm}$ for 5 minutes. The absorbance of haemoglobin content in the suspensions were estimated at $560 \mathrm{~nm}$. The percentage of haemolysis of HRBC membrane can be calculated as follows:

\section{Haemolysis (\%) = (Optical density of Test sample $/$ Optical density of Control) $\times 100$}

However, the percentage of HRBC membrane stabilization can be calculated as follows:

\section{Statistical analysis}

Results were expressed as mean \pm standard deviation in triplicates. Data was statistically analysed using $t$ test of Student as primary test followed by Fisher test with the criterion of $\mathrm{P}<0.05$ to determine whether there were any significant differences between methanol extract of $C$. africanum and standards, using Graphpad prism 5 Demo Software.

\section{RESULTS AND DISCUSSION}

The results obtained from the extraction method reveal an important yield (30\%) containing 43,49 $\pm 1,04 \mathrm{mg}$ EAG/GE of polyphenols and 2,48 $\pm 0,08 \mathrm{mg} \mathrm{QG} / \mathrm{GE}$ of flavonoids.

The DPPH radical was widely used in the model system to investigate the scavenging activities of several natural compounds [19]. The method is based on the reduction of alcoholic DPPH solutions in the presence of a hydrogendonating antioxidant [20]. Figure 1 shows the doseresponse curve for the radical-scavenging activity of $C$. africanum compared with BHT at the different concentrations by using the DPPH colouring method:

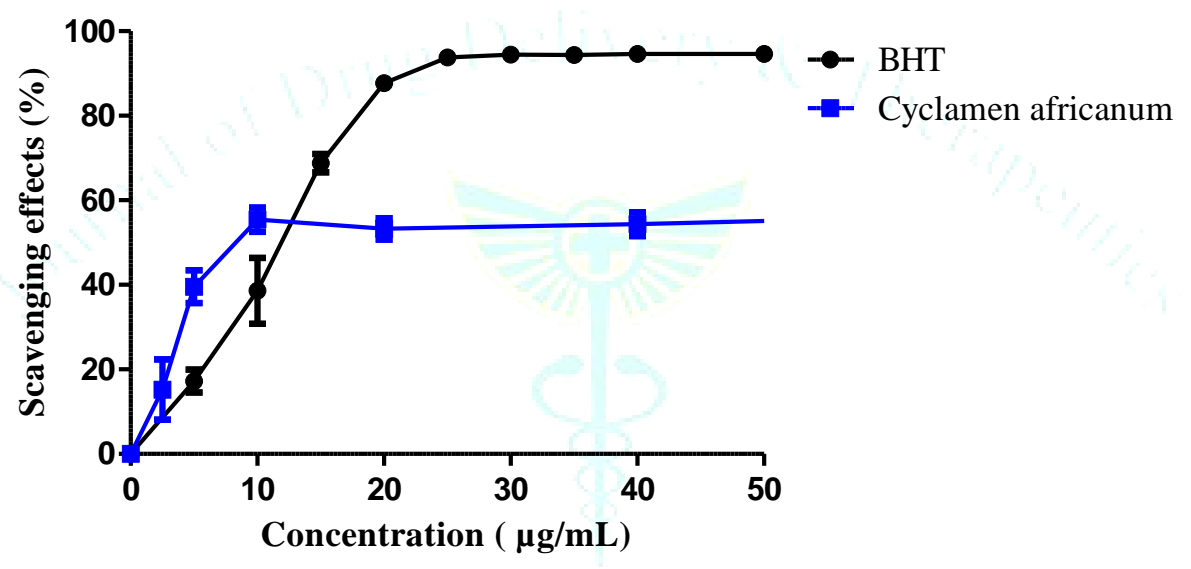

Figure 1: DPPH test of methanol extract of Cyclamen africanum B. et R.

A relatively higher antioxidant activity was observed in crude extract of $C$. africanum $\left(\mathrm{IC}_{50}=36,85 \pm 14,99 \mu \mathrm{g} / \mathrm{mL}^{* * *}\right.$ ) against the BHT $\left(\mathrm{IC}_{50}=6,29 \pm 1,12 \mu \mathrm{g} / \mathrm{mL}\right)$. The methanol extract of C. africanum showed $55,90 \pm 5,86 \%$ of antiradical effect at $80 \mu \mathrm{g} / \mathrm{mL}$, lower than standard drug.
It is well accepted that the DPPH radical scavenging by antioxidants is attributable to their hydrogen-donating ability [21].

The measure of the reduction of $\mathrm{Fe}^{3+}$ to $\mathrm{Fe}^{2+}$ ions is another method to observe the antioxidant activity, which is illustrated in Figure 2:

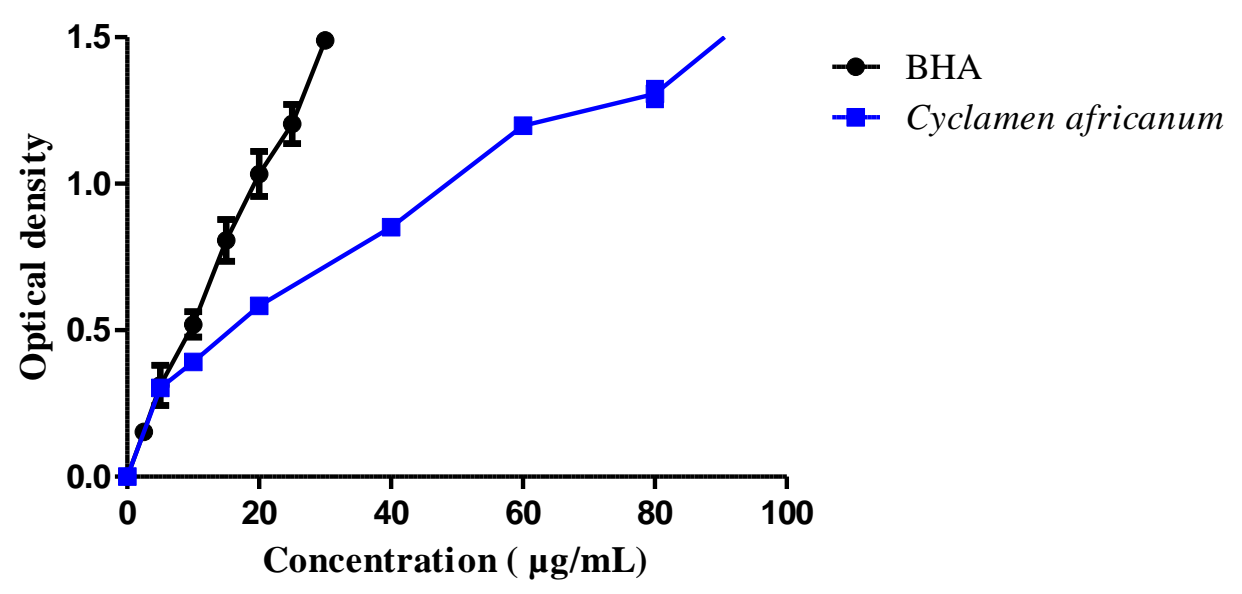

Figure 2: Reducing power activity of methanol extract of Cyclamen africanum B. et $\boldsymbol{R}$. 
The metal chelating activities of methanol extract of $C$. africanum and standards were concentration-dependent, indicate an excellent $\mathrm{EC}_{50}\left(12,73 \pm 0,57 \mu \mathrm{g} / \mathrm{mL}^{* * *}\right)$ against BHA $(9,51 \pm 0,12 \mu \mathrm{g} / \mathrm{mL})$.

Reducing power serves as a significant and sensitive parameter to assess potential antioxidant activity of plant extracts [22]. Hence, the ability of a compound to transfer electron is a significant indicator of its potential as an antioxidant [23]. Therefore, the methanol extract of C. africanum possess an excellent ability to transfer electrons.
A very weak antimicrobial power was registered $(7,17 \pm 0,24$ $\mathrm{mm}^{* * *}$ for Bacillus subtilis and 9,33 $\pm 0,47 \mathrm{~mm}^{* * *}$ for Klebsiella pneumonia) against gentamicin $(23,00 \pm 0,82 \mathrm{~mm}$ and $25,67 \pm 1,70 \mathrm{~mm}$ respectively).

The anti-inflammatory activity of $C$. africanum extract was confirmed by erythrocyte membrane stabilization test. The results (figure 3) show that human erythrocyte membranes were protected against hypotonic solution-induced lysis at different concentrations of extract, especially the smallest ones.

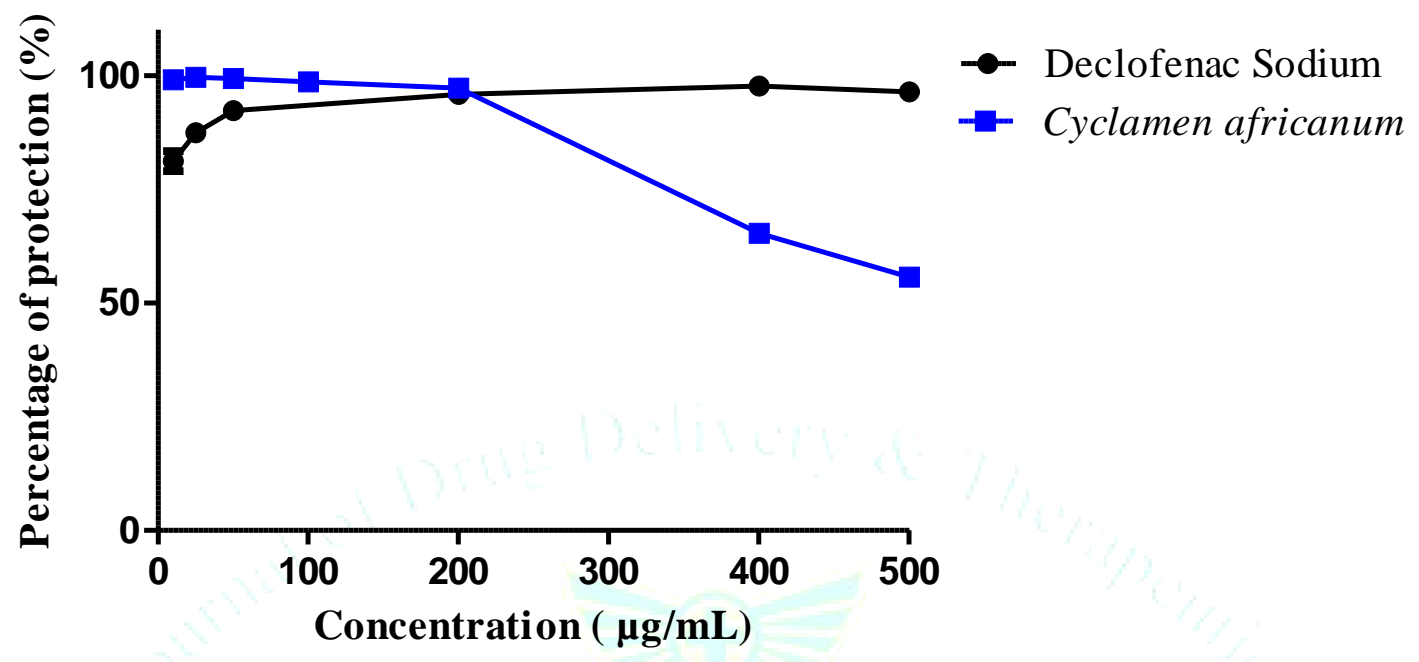

Figure 3: The percentage inhibition of hypotonicity induced haemolysis of HRBCs (\%) of standard and methanol extract of Cyclamen africanum B. et $R$.

Until a concentration of $200 \mu \mathrm{g} / \mathrm{mL}$ the extract shows an excellent capacities of erythrocytes membrane stabilisation, better than standard. This capacity decreases in high concentration $(400-500 \mu \mathrm{g} / \mathrm{mL})$ i.e the extract at 500 $\mu \mathrm{g} / \mathrm{mL}$ shows $55,72 \pm 0,63 \%{ }^{*}$ of erythrocytes protection against $96,40 \pm 0,10 \%$ of protection in case of Declofenac Sodium.

Membrane-stabilizing attributes were acknowledged for their power to interpose with release of phospholipases that activate the establishment of inflammatory intercessors [24]. During inflammation, lysosomal enzymes and hydrolytic components are released from the phagocytes to the extracellular space, which causes damages of the surrounding organelles and tissues and also assists a variety of disorders [25]. Hence, methanol extract of Cyclamen africanum act as an anti-inflammatory agent at a very small concentrations to give maximum effect.

\section{CONCLUSION}

Cyclamen africanum $B$. et $R$ is a north African endemic species where few studies have been done. This investigation reveals the biological potentialities of the crude extract of this species demonstrate a perfect capacity of donating electrons and hydrogen, also an excellent antiinflammatory activity in very small concentrations. However, a very weak antimicrobial power was observed. Hence, these results indicate that Cyclamen africanum crude extract can be a potential candidate for the development of new therapies for the treatment of inflammatory infections and a perfect antioxidant molecules sources.

\section{REFERENCES}

[1] Arne A, Anderberg, Ida T, and Mari K, Phylogeny of Cyclamen L. (Primulaceae): Evidence from morphology and sequence data from the internal transcribed spacers of nuclear ribosomal DNA. Plant Systematics and Evolution, 2000; (220):147-160.

[2] Emre 0, Samed K, Olcay Dinc D, and Ramazan M. Huseyin Cetin. Larvicidal activity of Cyclamen (Myrsinaceae) extracts against the larvae of West Nile virus vector Culex pipiens L. (Diptera: Culicidae). Asian Pacific Journal of Tropical Medicine. 2013; 449-452.

[3] Grey-Wilson C, Cyclamen A, Guide for Gardeners. Horticulturists and Botanists. New edition. Batsford, London. 2003.

[4] Yildirim M, Akcal A, and Kaynas K, The response of Cyclamen hederifolium to water stress induced by different irrigation levels. Afr. J. Biotechnol. 2009 ; (8):1069 - 1073.

[5] Speroni E, Cervellati R, Costa S, Dall'Acqua, S, Guerra M C, Panizzolo C, Utan A. and Innocenti, G, Analgesic and antiinflammatory activity of Cyclamen repandum $S$ et $S$ Phytother.; Res, 2007 ; (21):684-689.

[6] Leporatti M L, Ivancheva S. Preliminary comparative analysis of medicinal plants used in the traditional medicine of Bulgaria and Italy. J. Ethnopharmacol, 2003 ; 87:123-142.

[7] Quezel P and Santa S La nouvelle flore de l'Algerie et des regions désertiques meridionales. Editions du centre national de la recherche scientifique. Paris, France, 1963, p 1171.

[8] Neda S L, Neda M M D, Jelena M I. and Biljana N B Antioxidant properties of Galium verum L. (Rubiaceae) extracts, Cent. Eur. J. Biol. 2010; 331-337. 
[9] Li WD, Wei C L, White P J. and Beta T. High-amylose corn exhibits better antioxidant activity than typical and waxy genotypes. Journal of Agricultural and Food Chemistry, 2007; 55: 291-298.

[10] Bahorun T, Gressier B, Trotin F, Brunete C, Dine T , Vasseur J, Gazin J C, Pinkas M, Luycky M and Gazin M. Oxigen species scavenging activity of phenolic extract from howthorn fresh plant organs and pharmaceutical preparation. Arzneim Forsch / Drug Res,1996; 1-6.

[11] Hanato $T$, Kagawa $H$, Yasuhara $T$ and Okuda $T$. Two new flavonoids and other constituents in licorice root: Their relative astringency and radical scavenging effects. Chemical \& Pharmaceutical Bulletin, 1998; 2090-2097.

[12] R IBettaieb S, Bourgou I, Ben Slimen Debez I, Jabri Karoui I, Hamrouni Sellami K, Msaada, F Limam and B.Marzouk. Food Bioprocess Techno, 2011- 1007.

[13]M Oyaizu. 1986. Studies on products of browningreactions: antioxidative activities of products of browning reaction prepared from glucosaminutese, Japanese Journal of Nutrition, 1986; 307-315.

[14] SJ Huang and JL Mau. Antioxidant properties of methanolic extracts from Agaricus blazei with various doses of $\mathrm{\gamma}$ irradiation. Swiss Society of Food Science and Technology, 2006; 39:707-716.

[15] NCCLS (National Committee for Clinical Laboratory Standards). Performance standards for antimicrobial susceptibility testing. Wayne Pa. 9th International Supplement, 1999; M100-S9.

[16] NCCLS (National Committee for Clinical Laboratory Standards). Performance standards for antimicrobial disk susceptibility test. Wayne Pa. 6th ed. Approved Standard, 1997; M2-A6.
[17] Alves TMA, Silva AF, Brandão M, Grandi TSM, Smânia EFA, Smânia Jr A and Zani CL. Biological screening of Brazilian medicinal plants. Memórias do Instituto Oswaldo Cruz, 2000; 95:367-373.

[18] Seema C C, Sharan S V, Srinivasa R B and Meena V . In vitro anti-inflammatory activity of Methanolic extract of Centella asiatica by HRBC Membrane stabilization. Rasayan journal of chemistry, 2011; 4 (2):457-460.

[19] Huang DJ, Lin CD, Chen HJ, Hou WC and Lin YH. Active recombinant thioredoxin $h$ protein with antioxidant activities from sweet potato (Ipomoea batatas [L.] Lam 'Tainong 57') storage roots. J Agric Food Chem , 2004; 52:4720-4724.

[20] Pornpun Siramon and Yoshito Ohtani. Antioxidative and antiradical activities of Eucalyptus camaldulensis leaf oils from Thailand. J Wood Sci, 2007; 53:498-504.

[21] Chen CW, Ho CT. Antioxidant properties of polyphenols extracted from green and black tea. J Food Lipid, 1995; 2:35-46.

[22] Yen GC, Duh PD and Tsai CL. Relationship between antioxidant activity and maturity of peanut hulls. J Agric Food Chem, 1993; 41(1):67-70.

[23] Sudha G, Priya MS, Shree RI and Vadivukkarasi S. In vitro free radical scavenging activity of raw pepino fruit (Solanum muricatum). Int J Curr Pharm Res, 2011; 3(2):137-40.

[24] Aitadafouri M, Mounnnieri C, Heyman SF, Binistic C, Bon C and Godhold J .1996. 4-Alkoxybenzamides as new potent phospholipase A2 inhibitors. Biochem Pharm, 1996; 51:737742.

[25] Ackerman NR and Beebe JB. Release of lysosomal enzymes by alveolar mononuclear cells. Nature, 1974; 247:475-477. 